\author{
제주재래돼지 집단에서 집단특이적 mtDNA Haplotype과 \\ 유전적 다양성 \\ 한상현* . 조인철* . 이종언* . 이성수* · 강승률* · 최유림* · 오운용* · 성필남* · 고서봉* . \\ 오문유** . 고문석* \\ 농촌진흥청 난지농업연구소*, 제주대학교 생명과학과**
}

\title{
Genetic Variation and Population Specific Mitochondrial DNA Haplotype Found in the Jeju Native Pig Population
}

\author{
S. H. Han*, I. C. Cho,* C. E. Lee,* S. S. Lee,* S. Y. Kang,* Y. L. Choi,* W. Y. Oh,* \\ P. N. Sung,* S. B. Ko,* M. Y. Oh** and M. S. Ko* \\ National Institute of Subtropical Agriculture, R.D.A.*, \\ Department of Life Science, College of Natural Sciences, Cheju National University**
}

\begin{abstract}
Using PCR-RFLP haplotyping for the mitochondrial DNA(mtDNA) fragment containing the NADH dehydrogenase 2 gene(ND2) and three tRNA genes(tRNA-Met, tRNA-Trp and tRNA-Ala), we characterized the genetic diversity of five pig breeds including Jeju native pigs. mtDNA polymorphisms showing distinct cleavage patterns were found in the pig breeds. Two digestion patterns were detected when HaeIII- and HinfI-RFLP, and four in the Tsp509I-RFLP analyses. Combining the three restriction enzyme digestion patterns found in five different pig breeds, four mtDNA haplotypes were observed and the haplotype frequencies were significantly different by the pig breeds. A monomorphic haplotype, $m t W B$, was observed in both Korean wild boars and Large White pigs. Both Duroc and Landrace pigs contained two haplotypes suggesting their multiple maternal lineages. Jeju native pig has two haplotypes $(m t J N$ and $m t J D)$. Of these, $m t J N$ is identified as a Jeju native pig specific haplotype. This study suggested that more than two progenitor populations have been taken part in the domestication process of the Jeju native pig population, and/or probably subsequent crossing with other pig breeds from near east Asia. Unlike with our prediction, there was no direct evidence under molecular levels on the maternal introgression of Korean wild boar in the domestication of Jeju native pigs. In conclusion, specificity of mtDNA haplotypes related to pig breeds will be useful for identifying the maternal lineage as well as constructing the genealogical pedigree in pigs.
\end{abstract}

(Key words : Haplotype, Jeju native pig, Maternal origin, mtDNA, PCR-RFLP)

\section{I 서 론}

미토콘드리아 DNA(mtDNA)는 모계유전에 의 해 다음 세대로 전달되며, 염기치환 속도가 단 일사본 핵 유전자에 비해 10 배 정도 빠르기 때 문에(Brown 등, 1979; Giles 등, 1980; Wilson
등, 1985), 염기서열을 바탕으로 한 분자유전학 및 진화학 연구에 매우 유용한 분자 마커로써 이용되고 있다. 특히, 중요한 가축종인 돼지(Sus $s c r o f a)$ 의 경우 계통 형성과정 및 잡종화, 모계 혈통의 유입과 분산 경로 등을 추적하기 위해 mtDNA에 대한 연구가 활발히 수행되고 있다.

Corresponding author : M. S. Ko, National Institute of Subtropical Agriculture, R.D.A., Jeju, Jeju, 690-150, Korea. Tel : 064-741-2550, E-mail : koms21c@rda.go.kr 
돼지 mtDNA 전체 유전체와 조절부위인 control region과 12S 리보솜 RNA 유전자, cytochrome $\mathrm{B}(C Y T B)$ 유전자 등의 다형성과 haplotype에 관한 연구들은 유용한 정보들을 제공해 주고 있다 (Ursing과 Arnason, 1998; Lin 등, 1999; Giuffra 등, 2000; Kijas와 Andersson, 2001; Okumura 등, 2001; Yang 등, 2003; Kim 등, 2002; Alves 등, 2003; Watanobe 등, 2004). 돼지의 가축화는 약 6,000 10,000 년 전부터 아시아에서 최초로 시작되었고, 유럽에서도 독립적으로 진행된 것으로 추정되고 있으며, 18세기 이후 아시아 돼지들이 유럽으로 전파되어 육종에 이용된 것으로 알려지고 있으며 (Bökönyi, 1974; Watanabe 등 1985; Jones, 1998), 유럽돼지 계통에서 발견되어지는 아시아계열 특 이적 $\mathrm{mtDNA}$ 서열은 이 같은 가설을 입증하는 뒷받침하는 증거가 되고 있다(Huang 등, 1999; Giuffra 등, 2000; Alves 등, 2003).

한반도의 남서부에 위치한 제주도에는 소 (Bos taurus), 말(Equus caballus)을 비롯한 여러 종의 재래가축들이 사육되어 왔다. 제주도에서 가축사육의 역사는 적어도 2,000년 이상이며, 돼지 사육 역시 $\mathrm{AD} 0 \sim 400$ 년경에 시작되었을 것이며 아마도 야생멧돼지를 사육하거나 외부 에서 가축화된 돼지가 유입된 것으로 추정된 다. 제주도의 다양한 고대 유적지에서 다수의 돼지 유존체들이 발굴되었다(신 등, 1996; 제주 대학교박물관, 1997a; 1997b). 이들이 야생멧돼 지인지 가축돼지인지는 아직 명확히 제시된 바 없지만 두 가지 모두일 것으로 추정하고 있다. 현재 야생멧돼지는 절멸된 상태이고, 흑모색의 재래돼지들은 민간에서 사육하고 있다. 제주 재래돼지의 기원에 대해서는 여러 가지 주장들 이 있으나 체계적 근거는 제시되지 못하고 있다.

최근 야생동물을 비롯한 재래가축 유전자원 에 대한 학문적, 사회적 중요성이 부각되면서 동물유전체에 대한 연구들이 활발하게 진행되 고 있지만, 혈통의 정립과 진화의 추적, 계통유 연관계의 재조명 등 다양한 면에서 분자생물학 적 기초 자료들이 요구되고 있다. 제주도 재래 가축 중에서 재래마에 대한 연구를 통해 $\mathrm{mtDNA}$ 의 다형성에 근거한 계통유전학적 유연 관계와 집단의 모계에 유전적 특성들이 보고되
었다(Oh 등, 1994; Jung 등, 2002; Han 등, 2004). 제주 재래돼지에 대한 분자유전학적 연구 에서 Kim 등(2002)이 mtDNA D-loop 염기서열의 다형성에 대한 연구에서 제주 재래돼지는 아시아 계열이며 중국 재래돼지들과 근연의 관계라고 제 시하였고, 흑모색 형성에 관여하는 $M C 1 R$ 유전자 에 대한 연구에서 이 등(2001)과 조 등(2002, 2004) 은 제주 재래돼지에서 두 가지 유전자형을 보고 하였다. 아직까지 돼지 육종에 있어 분자유전학 적 실험기법을 통한 돼지 품종 간 구분의 기준이 마련되지 않은 상태일 뿐만 아니라 제주 재래돼 지 집단의 유전적 특성은 명확히 제시되어 있지 않고, 특히 재래돼지의 선별과 혈통 정립에서 핵 심으로 작용할 수 있는 집단 특이적인 분자 마커 역시 마련되지 못한 실정이다.

돼지 미토콘드리아 유전체에서 고도로 보존 적인 부위로 알려진 tRNA-Met, tRNA-Trp, tRNA-Ala 유전자들과 NADH dehydrogenase 2(ND2) 유전자를 포함하는 $\mathrm{mtDNA}$ 절편에서 PCR-RFLP 다형성을 기초한 haplotype 분석을 통해 현재 제주도에서 사육되고 있는 제주 재 래돼지 집단의 모계에 대한 분자유전학적 특성 을 살펴보고자 한다. 또한, 한반도 야생멧돼지 집단을 포함한 여러 품종의 돼지 집단들과의 비교를 통하여 제주 재래돼지 집단 특이적 haplotype을 찾고, 이를 바탕으로 모계의 기원 및 가축돼지의 유입경로를 추적하고, 돼지품종 들 사이에서 계통 유전학적 위치를 구명하고자 본 연구를 수행하였다.

\section{ㅍ 재료 및 방법}

\section{DNA 추출과 $\mathrm{PCR}$ 증폭}

제주도 농가에서 사육중인 재래돼지(65 두)에 서 수집한 혈액을 DNA 분리에 이용하였다. Duroc(47 두), Landrace(40 두), Large White(29 두)에서 채혈한 혈액과 야생멧돼지(14 두) 조직 에서 genomic DNA를 추출하였다. Genomic DNA 추출은 sucrose-proteinase $\mathrm{K}$ 방법(Birren 등, 1997)을 변형하여 수행하였고, 추출한 DNA 는 RNase(Sigma, USA)를 처리한 뒤 phenol extraction과 ethanol precipitation으로 정제하였고 
$\mathrm{DNA}$ 의 순도와 함량을 측정한 후, $\mathrm{PCR}$ 증폭에 이용하였다. PCR 증폭을 위한 primer는 돼지 mtDNA 염기서열(GenBank acc. No. NC_000845; Lin 등, 1999)을 근거로 제작하였다: $5008 \mathrm{HF}$ 5'-ACA TTC TAC AgT AAg gTC Ag-3', 6267LR 5'-gAC TTA gCT TAA TTA AAg Tg-3'. PCR 증폭은 Han 등(2004)의 방법을 일 부 변형하여 수행하였고, PCR 산물은 $1 \%$ agarose gel 상에서 전기영동 확인한 후, QIAEX II Gel Extraction Kit(Qiagen, USA)으로 정제하여 제한효소 절단과 cloning에 이용하였다.

\section{2. 제한효소 절단과 DNA 염기서열 결정}

PCR 산물은 3 종의 제한효소(HaeIII, HinfI, Tsp509I)를 이용하여 절단하였으며, 제한효소 반응 조건은 공급자의 manual에 따라 효소별 최적조건에서 overnight 반응하였다. $12 \sim 15 \%$ polyacrylamide gel 상에서 전개한 후, ethidium bromide 염색법으로 확인하였다. 제한절단 결과 발견된 절편 유형은 $\operatorname{Lin}$ 등(1999)에 의해 보고 된 서열과 동일한 양상을 보이는 형태를 각각 의 제한효소에 대한 제한절편 유형 $A$ 로 선정하 였다. 다형성의 확인을 위해 염기서열분석을 실시하였다. 먼저 정제한 $\mathrm{PCR}$ 산물을 $\mathrm{TOPO}$ TA Cloning Kit(Invitrogen, USA)의 pCR2.1 plasmid vector에 연결한 후 E. coli competent cell에 형질 전환 시켰다. 형질전환체인 plasmid는 WizardPlus SV Minipreps(Promega, USA)를 이용하여 분리 하고 염기서열 분석을 위한 주형으로 사용하였 다. 염기서열의 분석은 $\mathrm{ALF}^{\mathrm{TM}} \mathrm{Cy}^{\mathrm{TM}}$ AutoCycle DNA Sequencing Kit(Pharmacia Biotech, Sweden) 를 이용하여 결정하였고, 분석 결과를 돼지 mtDNA 유전체 서열인 GenBank accession No. NC_000845(Lin 등, 1999)와 비교 검토하였다.

\section{3. mtDNA haplotype 결정과 tRNA 구조 예측}

조사된 모든 개체에서 발견된 제한절편 유형들 을 조합하여 $\mathrm{mtDNA}$ 절편의 haplotype을 결정하였 다. tRNA 유전자 서열의 변이에 따른 tRNA 구 조 변화를 확인하기 위해 tRNAscan-SE web program(Lowe와 Eddy, 1997; http://www.genetics.
wustl.edu/eddy/tRNAscan-SE/)으로 2차 구조를 예 측하였다.

\section{III 결과 및 고찰}

\section{PCR-RFLP 다형현상}

제주 재래돼지를 포함한 5 품종의 돼지 집단 에서 세 종류의 tRNA 유전자들(tRNA-Met, tRNATrp, tRNA-Ala)과 ND2 유전자가 포함된 mtDNA 절편은 3 종의 제한효소 PCR-RFLP에서 다형현 상을 나타내었다. 이중 Tsp509I은 돼지 종 내에서 4 가지 제한절편 유형들을 나타내었고, 다른 2 종에 의한 제한절편들은 각각 2 가지 유형으로 구분되었다(Fig. 1). 흥미로운 점은 Tsp509I에 의한 다형현상을 제외한 두 가지 제한효소 (HaeIII, HinfI) 다형현상의 출현 양상이 동일 개 체 내에서는 완전히 연관되어 있다는 것이다. 제 주 재래돼지 집단에서는 3 종의 제한효소 모두에 서 절편 길이의 다형현상이 관찰되었고, Tsp509I 제한절편 유형 중에서는 $T s B$ 와 $T s D$ 가 관찰되었 다. Duroc은 3 종의 제한효소 모두에서 다형현상 이 관찰되었으나, Landrace는 Tsp509I에서만 다형 현상이 관찰되었다. 한반도 야생멧돼지와 Large White 집단에서는 제한효소에 의한 집단 내 다형 현상은 관찰되지 않았다(Table 1).

\section{2. tRNA-Met와 ND2 유전자의 개시코돈 다} 형성

제한효소 Tsp509I 인지부위에 대한 다형현상 중 $\mathrm{T5089A}$ 는 ND2 유전자 개시코돈의 염기치환 을 나타내는 선택적 개시코돈(alternative initiation codon, AIC) 형태로 확인되었다. 이는 여러 돼 지 품종들의 mtDNA 유전체 서열에서 두 가지 개시코돈이 존재한다는 기존의 보고들을 지지 해주는 결과이다. Ursing과 Arnason(1998)은 돼 지 미토콘드리아에서 단백질 해독과정에서 개 시 아미노산 methionine에 대한 코돈서열로 ATG가 대부분이지만 ATA가 출현하기도 하고, $N D 2$ 에서는 ATT(isoleucine), ND4L에서는 GTG (valine) 등이 개시코돈의 위치에서 발견된다고 기술하였다. ND2 유전자의 ATT 개시코돈은 가 


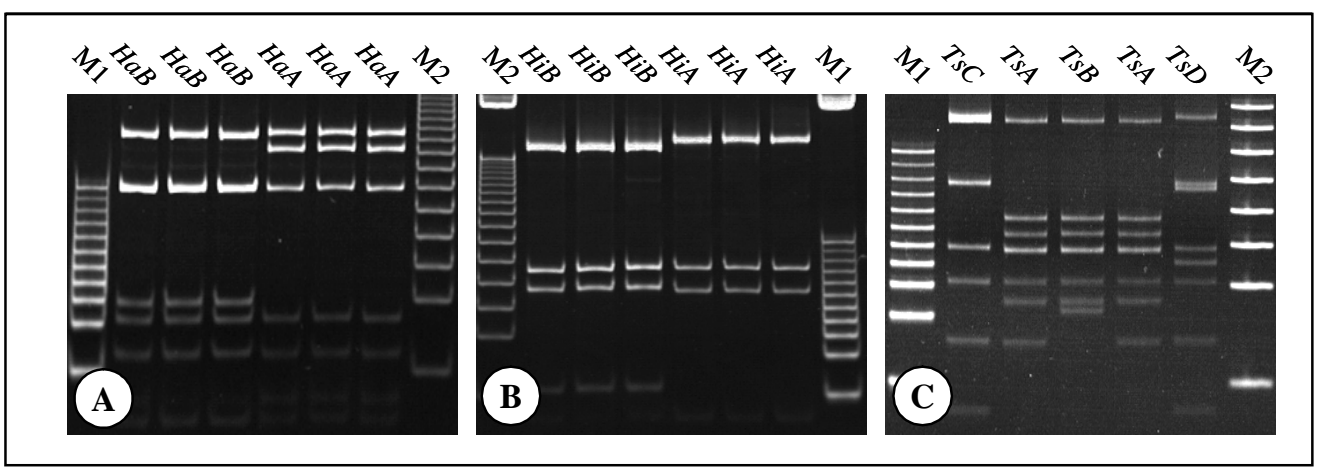

Fig. 1. Cleavage patterns obtained from restriction digestion. A, Haelll; B, Hinfl; C, Tsp509I. Symbols of each restriction enzyme digestion patterns were described in Table 1. M1 is 25-bp DNA step ladder, and M2 is 50-bp DNA step ladder, respectively.

Table 1. Restriction enzyme digestion patterns and their frequencies from the five pig breeds

\begin{tabular}{|c|c|c|c|c|c|c|c|c|}
\hline \multirow{2}{*}{ Enzyme } & \multirow{2}{*}{$\begin{array}{c}\text { Digestion } \\
\text { pattern } \\
\end{array}$} & \multirow{2}{*}{$\begin{array}{c}\text { JNP* } \\
(\mathrm{n}=65) \\
\end{array}$} & \multirow{2}{*}{$\begin{array}{l}\mathrm{KWB}^{* *} \\
(\mathrm{n}=14) \\
\end{array}$} & \multirow{2}{*}{$\begin{array}{c}\text { Duroc } \\
(\mathrm{n}=47) \\
\end{array}$} & \multirow{2}{*}{$\begin{array}{c}\text { Landrace } \\
(\mathrm{n}=40)\end{array}$} & \multirow{2}{*}{$\begin{array}{c}\text { Large White } \\
(\mathrm{n}=29)\end{array}$} & \multicolumn{2}{|c|}{ Total $(n=195)$} \\
\hline & & & & & & & $n$ & $\%$ \\
\hline \multirow[t]{2}{*}{ HaeIII } & $\overline{\mathrm{HaA}}$ & 19 & 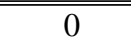 & 37 & 40 & 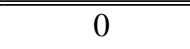 & 96 & 499.2 \\
\hline & $H a B$ & 46 & 14 & 10 & 0 & 29 & 99 & 50.8 \\
\hline \multirow[t]{2}{*}{ HinfI } & $H i A$ & 19 & 0 & 37 & 40 & 0 & 96 & 49.2 \\
\hline & $H i B$ & 46 & 14 & 10 & 0 & 29 & 99 & 50.8 \\
\hline \multirow[t]{4}{*}{ Tsp509I } & TsA & 19 & 0 & 37 & 8 & 0 & 64 & 32.8 \\
\hline & $T s B$ & 0 & 0 & 0 & 32 & 0 & 32 & 16.4 \\
\hline & Ts $C$ & 0 & 14 & 10 & 0 & 29 & 53 & 27.2 \\
\hline & $T s D$ & 46 & 0 & 0 & 0 & 0 & 46 & 23.6 \\
\hline
\end{tabular}

* Jeju native pig, ** Korean wild boar.

축돼지인 Landrace와 Duroc에서 확인되었고 Sweden 야생멧돼지의 mtDNA 서열에서도 확인 되었다(Lin 등, 1999; Ursing과 Arnason, 1998; Kijas와 Andersson, 2001). 기존의 연구에서는 단지 ND2 유전자 서열상에서 $\mathrm{AIC}$ 가 출현한다 는 언급만 있을 뿐이었으나 본 연구결과는 AIC 양상이 집단 내 일정한 빈도를 나타내는 다형현상의 일종으로 관찰되었다(Table 1). AIC 양상과 관련되어 매우 흥미로운 점은 현재까지 보고된 돼지 mtDNA 서열들에서 tRNA-Met의 안티코돈 서열은 매우 보존적이며 CAU만 나타 내며, 이 같은 양상은 기존에 보고된 포유동물 의 tRNA-Met 안티코돈 서열에 대한 비교분석 에서도 염기변이는 관찰되지 않았다(data not shown). 본 연구에서 염기서열 분석 결과 tRNAMet 유전자 서열의 다형현상은 T5039C만이 Duroc과 한반도 야생멧돼지 집단에서 관찰되었 고, tRNA-scanSE program으로 tRNA의 2차 구
조를 예측했을 때, tRNA의 stem과 D loop의 연 결부위에서 $\mathrm{T} 5039 \mathrm{C}$ 는 A-U 수소결합이 형성되 지 않음을 확인하였다(Fig. 2).

\section{3. 품종 특이적 mtDNA haplotype}

조사된 모든 개체에 대한 제한절편 유형들을 조합한 결과 4 가지 mtDNA haplotype들로 구분 되었다. 한반도 야생멧돼지와 Large White 집단 은 각각 하나의 haplotype $m t W B$ 만을 나타내었 고, Duroc, Landrace, 제주 재래돼지 집단들을 각각 두 가지 haplotype들로 구분되었다(Table 2). 한반도 야생멧돼지와 Large White에서 나타 나는 공통의 haplotype $m t W B$ 는 이들 두 집단이 공통의 모계 선조에서 유래되었음을 시사한다. 기존의 연구에 따르면, Large White는 유럽을 원산으로 하고 있으나 품종 형성과정에서 아시 아(중국) 돼지를 도입하여 산자수(litter size) 증 


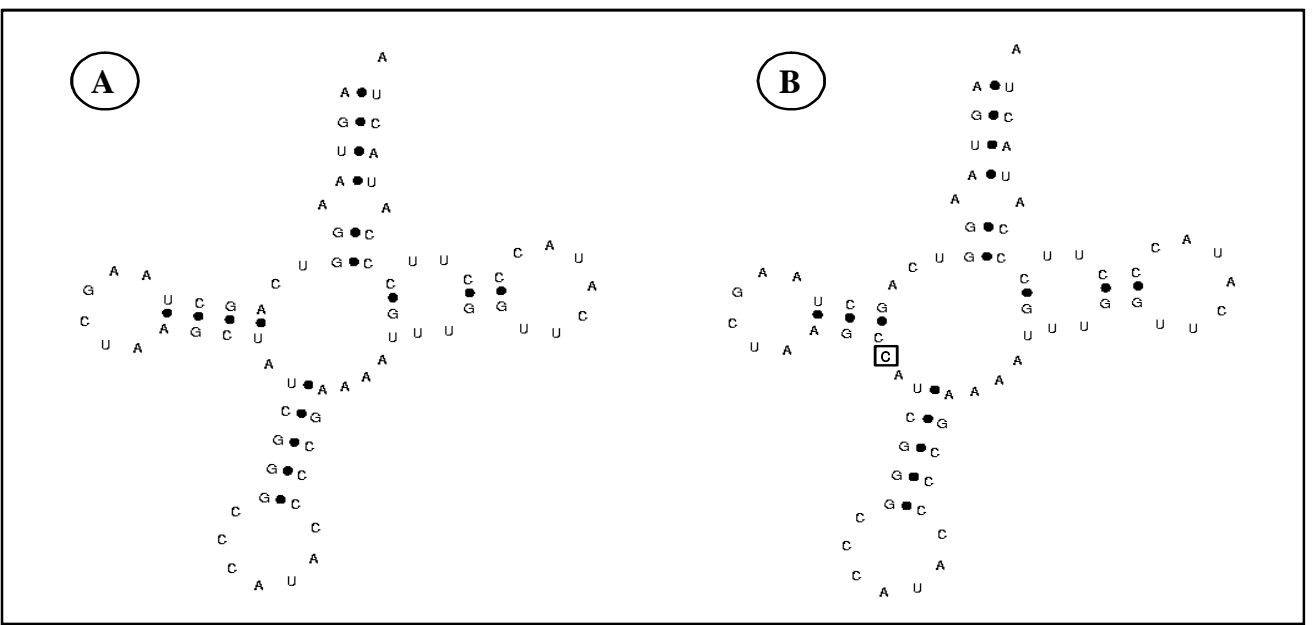

Fig. 2. Secondary structures of the tRNA-Met predicted by tRNA-scanSE. A, a tRNA-Met sequence $1 ; \mathrm{B}$, a tRNA-Met sequence 2 containing the nucleotide substitution T5039C. The capital letter in the rectangle indicates the nucleotide substitution T5039C.

Table 2. The mtDNA haplotypes obtained from combining the three restriction enzyme digestion patterns

\begin{tabular}{|c|c|c|c|c|c|c|c|c|c|c|}
\hline \multirow{2}{*}{ Haplotype } & \multicolumn{3}{|c|}{ Enzyme digestion pattern } & \multirow{2}{*}{$\begin{array}{c}\text { JNP } \\
(\mathrm{n}=65)\end{array}$} & \multirow{2}{*}{$\begin{array}{l}\text { KWB } \\
(n=14)\end{array}$} & \multirow{2}{*}{$\begin{array}{c}\text { Duroc } \\
(\mathrm{n}=47)\end{array}$} & \multirow{2}{*}{$\begin{array}{c}\text { Landrace } \\
(\mathrm{n}=40)\end{array}$} & \multirow{2}{*}{$\begin{array}{l}\text { Large White } \\
\qquad(\mathrm{n}=29)\end{array}$} & \multicolumn{2}{|c|}{ Total $(n=195)$} \\
\hline & HaeIII & HinfI & Tsp509I & & & & & & $\mathrm{n}$ & $\%$ \\
\hline$m t J D$ & HaA & HiA & $\overline{T S A}$ & 19 & 0 & 37 & 8 & 0 & 64 & 32.8 \\
\hline$m t L R$ & $H a A$ & HiA & $T s B$ & 0 & 0 & 0 & 32 & 0 & 32 & 16.4 \\
\hline$m t W B$ & $H a B$ & $H i B$ & $\mathrm{Ts} C$ & 0 & 14 & 10 & 0 & 29 & 53 & 27.2 \\
\hline$m t J N$ & $H a B$ & HiB & $T s D$ & 46 & 0 & 0 & 0 & 0 & 46 & 23.6 \\
\hline
\end{tabular}

가의 목적으로 모돈으로 이용한 것으로 보고되 고 있다(Huang 등, 1999; Giuffra 등, 2000). 본 연구 결과에서 나타나는 한반도 야생멧돼지와 의 공통 haplotype은 Large White 품종이 아시 아 유래라는 설을 뒷받침하고 있으며, 나아가 Large White의 개량에 이용된 중국 돼지와 한 반도 야생멧돼지가 공통의 모계에서 유래되었 을 것으로 추정된다(Kim 등, 2002). 한편, Duroc 과 Landrace 품종 집단들은 각각 두 가지 haplotype들로 구분되었고 $m t J D$ 는 공통으로 출현 하였다. 이는 이들 품종들이 적어도 둘 이상 의 모계를 기원으로 하고 있음을 시사하고 있다. Duroc 품종에서 나타난 결과는 조 등 (2003)에 의해 보고된 mtDNA control region duplication motif의 출현 양상과 유사한 결과이 나, 본 연구에서 조사된 haplotype과 duplication motif 출현의 연관은 차후 지속적인 연구를 통
해 분석되어야 할 것이다. Duroc과 Landrace에 서 발견되는 haplotype들과 염기서열의 다형성 은 control region과 CYTB 유전자 분석에서 제 시된 haplotype의 다양성과 이들 품종의 모계 가 유럽을 원류로 하지만 육종과정에서 다른 지역에서 유입된 돼지집단들과 유전자원의 교 류가 있었다는 가설을 지지해 주는 결과이다 (Okumura 등, 2001; Alves 등, 2003). 제주 재 래돼지 집단에서도 두 가지 haplotype들 $(m t J D$, $m t J N)$ 이 발견되었고, 이 중 $m t J D$ 는 Duroc, Landrace와 공통이지만 $m t J N$ 은 제주 재래돼지 집단에서 특이적으로 관찰되었다. 발견된 haplotype 중에서 $m t J D$ 는 19 두(29.2\%) $m t J N$ 은 46 두(70.7\%)로 관찰되어, 제주 재래돼지 집단 특이적인 haplotype의 빈도가 훨씬 높게 나타났 다(Table 2). 


\section{4. 제주 재래돼지 집단의 모계 선조}

모계 유전의 특성과 빠른 진화속도를 나타내 는 mtDNA에 대한 haplotype과 유전적 변이를 조사한 본 연구 결과를 살펴보면, 제주 재래돼 지 집단의 모계 기원에 대한 몇 가지 가설을 유추해 낼 수 있었다. 먼저, 제주 재래돼지 집 단에서 두 가지 haplotype $m t J N$ 와 $m t J D$ 가 발견 되어 이들 haplotype들이 제주 재래돼지 집단의 모계 선조인 두 가지 큰 지류라고 할 수 있을 것이다. 하지만 연구진의 예상과는 달리 제주 돼지 집단에서 발견된 두 haplotype들이 한국 야생멧돼지 집단에서 관찰되지 않기 때문에 제 주 돼지 집단의 형성과정에서 한반도에 서식하 는 야생멧돼지들은 모계 선조로써 이용되지는 않았다고 사료된다. 제주 재래돼지 집단에서 발 견된 haplotype 중에서 $m t J D$ 는 Duroc과 Landrace 집단에서 공통으로 확인되었고, 이 결과는 이 들 집단들 사이의 인위적인 교배에 의한 것으 로 의심할 만 하다. 조 등(2002)의 연구에서 흑 모색 형성에 관여하는 $M C 1 R$ 유전자의 대립인 자형에 조사에서 백색 계열인 Landrace 품종에 의한 모계 유입 가능성은 없다고 추정되나, 적 색인 Duroc의 유전자형은 흑모색에 대한 열성 을 나타내고 육성과정에서 열성형질을 나타내 는 개체들을 도태할 경우 흑모색을 나타낼 수 있기 때문에 Duroc 품종에 의한 모계 유입 가 능성은 여전히 남아 있다고 하겠다.

본 연구 결과에서 주목해야할 중요한 사실은 제주 재래돼지 집단에서 3 품종 가축돼지 집단 들(Duroc, Landrace, Large White)과 한반도 야생 멧돼지 집단에서도 전혀 관찰되지 않는 haplotype $m t J N$ 이 특이적으로 출현하며 높은 빈도 (70.7\%)로 관찰된다는 점이다. 높은 빈도의 haplotype $m t J N$ 이 나타내는 제주 재래돼지 집단 특이성은 대다수의 개체들이 3 품종의 가축돼지 및 한반도 야생멧돼지들과는 별개의 모계 선조 에서 유래된 것임을 시사한다. 비록 비교 집단 의 수와 개체군의 수가 적기 때문에 본 연구결 과만으로 haplotype $m t J N$ 을 나타내는 개체들이 제주 재래돼지라고 단정하기에는 무리가 없지 않지만 적어도 Duroc이나 Landrace, Large White 품종뿐만 아니라 한반도 야생멧돼지에
의한 모계 유입이 배제된 집단이라고 규정할 수 있을 것으로 사료된다. Kim 등(2002)은 제 주 재래돼지 3 두의 control region 서열이 중국 재래돼지들과 함께 아시아 고유의 cluster에서 발견되고, 한국과 일본의 돼지들이 중국의 돼 지들과 근연의 관계임을 제시한 바 있으나, 본 연구에서 중국과 일본의 돼지들에 대한 조사가 없어 이들 집단들과의 비교가 뒷받침되어야할 것으로 사료된다.

예로부터 제주도에는 소, 말, 돼지를 비롯한 여러 종의 재래가축들이 사육되어 왔다. 현재 까지 제주 재래가축의 기원에 대한 명확한 자 료는 제시되고 있지 않지만, 돼지를 비롯한 가 축사육의 역사는 매우 오랜 것으로 추정된다. 역사서 기록과 유적지에서 출토된 유존체에 대 한 분석을 보면, 기원전부터 많은 수의 포유동 물들이 서식했을 것이고 이들 중 대다수가 소와 돼지의 유존체로 확인되고 있다(신 등, 1996; 제주대학교박물관, 1997a; 1997b). 현재까지의 연구 결과들을 토대로 추측해 볼 때 가축 사육 의 역사도 A.D. 0년을 전후해서 시작된 것으로 보이며, 제주도에서 돼지의 가축화는 두 가지 경로로 추정된다. 첫째, 고대에 서식하고 있던 어린 멧돼지를 제사의식과 섭식을 위한 사육에 서 시작되었을 것이고, 둘째, 가축화된 돼지는 A.D. $200 \sim 400$ 년 이후 아시아 인근 지역으로부 터 도입되었을 가능성을 추정할 수 있다. 유적 지에서 출토된 돼지 또는 멧돼지 유존체에 대 한 분자유전학적 연구가 시도되고 있으며, 모 계 선조로써 고대 돼지 유전자원의 유입은 충 분히 고려되어야할 것으로 사료된다. 재래가축 의 기원에 대한 연구들 중에서 현생 제주 재래 마와 고대 유존체 mtDNA에 대한 연구에서 여 타 다른 계통에서 발견되지 않는 특이적인 mtDNA haplotype들을 확인하였고, 이를 통해 고대동물이 현존하는 재래마의 선조일 가능성 을 제기한 바 있다(Oh 등, 1994; Jung 등, 2002; 김, 2003; Han 등, 2004). 생물지리학적 관점에 서 대륙과 제주도 사이에서 육상동물의 자연적 인 이동이 불가능하다는 점과 역사적으로도 다 수의 가축들을 사육했었던 점을 미루어보아 당 시 풍부했던 야생동물을 가축화했을 가능성 또 한 대단히 높다고 하겠다. 또한, 단순히 야생동 
물을 가축화하여 이용하는 수준을 벗어나 이후 아시아 인근 지역의 재래가축들과의 교류와 교 잡이 이루어졌을 것으로 추정된다.

해방이후 재래돼지 개체군이 급격히 감소되 었고, 1970년대 이후 재래돼지의 능력개량을 위해 외래 유전자원의 도입으로 현재 제주도에 서 사육되고 있는 돼지의 순수 토종집단 여부 가 관심의 대상이 되고 있다. 1980년 이후 재 래돼지의 혈통 유지와 개체군의 확보에 대한 필요성이 부각되어 이를 복원하기 위한 노력들 이 다각적으로 진행되고 있으나, 순수 혈통을 판독할 수 있는 분자유전학 기준의 부재는 향 후 재래돼지 집단 확보에 있어 의심할 여지없 이 가장 큰 문제로 작용할 것이다. 비록 집단 형성과 동시에 유전적인 특성을 규명하는 연구 가 진행되지는 않았으나, 앞으로 더 많은 해석 상의 오류나 혈통 정립의 문제를 해결하는 데 있어 본 연구는 단편적이나마 지대한 영향을 미칠 수 있을 것으로 사료된다. 본 연구 결과 가 제주 재래돼지 집단의 기원과 혈통 규명뿐 만 아니라 계통간 교잡을 확인하는 데 있어 매 우 유용한 자료가 될 것임은 틀림없는 사실이 지만, 분석에 이용한 집단의 수와 개체 수의 한계는 명확한 계통 형성 과정을 추정하기는 다소 무리가 없지 않다. 향후 재래돼지의 집단 형성에 참여했을 것으로 추정되는 후보 집단의 폭을 과거에 서식했을 고대 돼지 유존체, 한반 도, 중국, 일본을 포함한 인근 아시아 지역 재 래돼지 및 야생멧돼지 집단들까지 넓히고, $S R Y$, $A M E L X, A M E L Y, \mathrm{mtDNA}$ 유전체 서열 등 모계 와 부계 선조를 추적할 수 있는 적절한 분자 마커들에 대한 세밀한 연구를 통해 자료를 보 완한다면, 제주 재래돼지를 포함한 아시아 돼 지의 가축화와 진화과정 연구에 획기적인 성과 를 제시할 수 있을 것이다.

\section{IV 요 약}

미토콘드리아 ND2 유전자와 세 가지 tRNA (tRNA-Met, tRNA-Trp, tRNA-Ala)들이 포함하는 mtDNA 절편의 PCR-RFLP haplotyping 기법으로 제주도에서 사육하는 한국 재래돼지를 포함하 는 5 개 품종에 대한 유전적 다양성을 조사하였
다. 몇몇 돼지 품종에서 mtDNA 상의 제한절편 길이의 다형성이 관찰되었다. HaeIII-와 HinfIRFLP에서는 두 가지 제한절편 유형, Tsp509IRFLP에서는 네 가지 유형으로 각각 구분되었 다. 발견된 제한절편 유형들을 조합하여 mtDNA haplotype으로 구분했을 때, 모두 네 가지 haplotype들이 발견되었고 집단에 따라 각기 다른 빈도를 나타내었다. 하나의 동일한 haplotype $m t W B$ 가 한반도 야생멧돼지와 Large White 집 단에서 관찰되었다. Duroc과 Landrace 품종들은 여러 모계 선조에서 유래되었을 것으로 추정되 는 두 가지의 haplotype들을 가지고 있었다. 제 주도에서 사육되고 있는 한국재래돼지 집단에 서는 $m t J D$ 와 $m t J N$ haplotype들이 관찰되었는데, 이 중 $m t J N$ 은 빈도가 높고 집단 특이적이었다. 본 연구의 결과는 제주 돼지 집단의 형성에 적 어도 둘 이상의 모계 선조가 참여했으며, 이후 동아시아 인근 돼지 품종들과의 인위적인 교잡 이 이루어졌을 것으로 추정된다. 연구진의 예 상과는 달리 한반도 야생멧돼지가 제주 재래돼 지 집단의 모계 선조라는 증거는 확인되지 않 았다. MtDNA haplotype과 돼지 계통간의 관계 에서의 특이성은 돼지 육종에 있어 모계 확인 과 계보 구성에 매우 유용한 정보를 제공할 것 으로 사료된다.

$$
\mathrm{V} \text { 사 사 }
$$

본 연구는 2004년도 농촌진흥청 난지농업연 구소 박사후연수과정사업의 지원에 의해 이루 어진 것임.

\section{$\mathrm{VI}$ 인 용 문 헌}

1. Alves, E., Ovilo, C., Rodriguez, M. C. and Silio, L. 2003. Mitochondrial DNA sequence variation and phylogenetic relationships among Iberian pigs and other domestic and wild pig populations. Anim. Genet. 34:319-324.

2. Birren, B., Green, E. D., Klapholz, S., Myers, R. M. and Roskams, J. 1997. Genome analysis: A laboratory manual. Cold Spring Harbor Laboratory Press, USA.

3. Brown, W. M., George, M. and Wilson, A. C. 1979. Rapid evolution of animal mitocondrial DNA. Proc. Natl. Acad. Sci. USA. 76:1967-1971. 
4. Bökönyi, S. 1974. History of Domestic Mammals in Central and Eastern Europe. Academiai Kiado, Budapest.

5. Giles, R. E., Blanc, H., Cann, H. M. and Wallace, D. C. 1980. Maternal inheritance of human mitochondrial DNA. Proc. Natl. Acad. Sci. USA. 77:6715-6719.

6. Giuffra, E., Kijas, J. M. H., Amarger, V., Carlborg, O., Jeon, J. T. and Andersson, L. 2000. The origin of the domestic pig: independent domestication and subsequent introgression. Genetics. 154:1785-1791.

7. Han, S. H., Kim, J. H., Song, J. H., Oh, J. H., Oh, Y. S., Jung, Y. H., Kayano, H. and Oh, M. Y. 2004. Polymorphism of the mtDNA cytochrome $\mathrm{B}$ and NADH dehydrogenase 6 genes in Tsushima and Jeju native horses. Korean J. Genetics. 26:1-7.

8. Huang, Y., Shi, X. and Zhang, Y. 1999. Mitochondrial genetic variation in Chinese pigs and wild boars. Biochem. Genet. 37:335-343.

9. Jones, G. F. 1998. Genetic aspects of domestication, common breeds and their origins. In: Ruvinsky, A., Rothschild, M. F.(eds) The genetics of the pig. $C A B$ International, Oxon, UK, pp. 17-50.

10. Jung, Y. H., Han, S. H., Shin, T. K. and Oh, M. Y. 2002. Genetic characterization of horse bone excavated from the Kwakji archaeological site, Jeju, Korea. Mol. Cells. 14:224-230.

11. Kijas, J. M. H. and Andersson, L. 2001. A phylogenetic study of the domestic pig estimated from the near-complete mtDNA genome. J. Mol. Evol. 52:302-308.

12. Kim, K. I., Lee, J. H., Li, K., Zhang, Y. P., Lee, S. S., Gongora, J. and Moran, C. 2002. Phylogenetic relationships of Asian and European pig breeds determined by mitochondrial DNA D-loop sequence polymorphism. Anim. Genet. 33:19-25.

13. Lin, C. S., Sun, Y. L., Liu, C. Y., Yang, P. C., Chang, L. C., Cheng, I. C., Mao, S. J. and Huang, M. C. 1999. Complete nucleotide sequence of pig(Sus scrofa) mitochondrial genome and dating evolutionary divergence within Artiodactyla. Gene. 236:107-114.

14. Lowe, T. M. and Eddy, S. R. 1997. tRNAscan-SE: a program for improved detection of transfer RNA genes in genomic sequence. Nucl. Acids Res. 25: 955-964.

15. Oh, M. Y., Ko, M. H., Kim, G. O., Oh, Y. S., Kim, S. J. and Hong, S. S. 1994. Phylogenetic relationship of Cheju native horses by mitochondrial DNA analysis. Mol. Cells. 4:13-20.

16. Okumura, N., Kurosawa, Y., Kobayashi, E., Watanobe, T., Ishiguro, N., Yasue, $\mathrm{H}$. and Mitsuhashi, T. 2001. Genetic relationship amongst the major non-coding regions of mitochondrial
DNAs in wild boars and several breeds of domesticated pigs. Anim. Genet. 32:139-147.

17. Ursing, B. M. and Arnason, U. 1998. The complete mitochondrial DNA sequence of the pig(Sus scrofa). J. Mol. Evol. 47:302-306.

18. Watanabe, T., Hayashi, Y., Ogasawara, N. and Tomita, T. 1985. Polymorphism of mitochondrial DNA in pigs based on restriction endonuclease cleavage patterns. Biochem. Genet. 23:105-113.

19. Watanobe, T., Ishiguro, N., Nakano, M., Matsui, A., Hongo, H., Yamazaki, K. and Takahashi, O. 2004. Prehistoric Sado Island populations of Sus scrofa distinguished from contemporary Japanese wild boar by ancient mitochondrial DNA. Zoolog. Sci. 21:219-228.

20. Wilson, A. C., Cann, L., Carr, S. M., George, M. and Gyllensten, U. B. 1985. Mitochondrial DNA and two perspectives on evolutionary genetics. Biol. J. Linn. Soc. 26:375-400.

21. Yang, J., Wang, J., Kijas, J., Liu, B., Han, H., Yu, M., Yang, H., Zhao, S. and Li, K. 2003. Genetic diversity present within the near-complete mtDNA genome of 17 breeds of indigenous Chinese pigs. J. Hered. 94:381-385.

22. 김재환. 2003. 제주도 고대 유적지로부터 발굴된 동물 뼈의 mitochondria DNA의 유전 분석. 제주 대학교 석사학위논문.

23. 신태균, 진재광, 이차수. 1996. 제주 김녕리 궤내 기 동굴 유적에서 출토된 뼈유물의 고고학적 연 구. 대한수의학회지. 36:757-761.

24. 이성수, 양보석, 정진관, 고서봉, 오성종, 양영훈, 김규일, 李贊東, 馮書堂. 2001. 재래 흑돼지와 중 국 재래돈간의 Melanocortin Receptor 1(MC1R) 유 전자의 유전자형 분석. 한국동물자원과학회지. 43:1-8.

25. 제주대학교박물관. 1997a. 제주 종달리 패총. 북 제주군. pp. 101-108.

26. 제주대학교박물관. 1997b. 제주 곽지 패총. 북제 주군. pp. 252-255.

27. 조인철, 이정규, 정진관, 양보석, 강승률, 김병우. 2002. 랜드레이스, 대요크셔, 듀록 및 제주 흑돈 의 Melanocortin 1 Receptor(MC1R) 유전자의 유전 자형 분석. 한국동물자원과학회지 44:207-212.

28. 조인철, 정용환, 정진관, 성필남, 김병우, 이정규, 전진태. 2003. Single stranded conformation polymorphism 분석에 의한 돼지 Duroc 품종의 미토 콘드리아 DNA 유전적 변이. 한국동물자원과학회 지. 45:911-916.

29. 조인철, 정용환, 정진관, 성필남, 오운용, 고문석, 김병우, 이정규, 전진태 2004. 돼지 Melanocortin Receptor $1(M C 1 R)$ 대립유전자 3의 신규 유전변이 탐색. 한국동물자원과학회지 46:1-6.

(접수일자 : 2004. 9. 10. / 채택일자 : 2004. 11. 2.) 